\title{
Stella Kaczmarek*
}

\section{Stres menedżera pracującego w warunkach międzykulturowych i międzynarodowych}

Streszczenie: $w$ niniejszym tekście przedstawione zostaną problemy współczesnego menedżera pracującego w warunkach międzynarodowych. Właśnie ta grupa pracowników przedsiębiorstwa jest narażona na dużą dawkę stresu związanego z warunkami pracy, presją czasu oraz ilością terminów/projektów. Można nawet stwierdzić, że nową umiejętnością - cenioną u współczesnego menedżera - jest duża odporność na stres oraz work-life balance.

Słowa kluczowe: menedżer, stres, korporacja międzynarodowa, warunki międzykulturowe

\section{Wprowadzenie}

Współczesny menedżer to niewątpliwie człowiek, który posiada umiejętności radzenia sobie z trudnymi sytuacjami zawodowymi. Oznacza to, że jedną z istotnych kompetencji na stanowisku kierowniczym jest odporność na stres. Jednakże ważne jest również, by menedżer nie tylko radził sobie ze stresem zawodowym, ale potrafił nim zarządzać w odniesieniu do poszczególnych pracowników i całej organizacji.

Pracownicy i menedżerowie średniego szczebla w ok. 50\% przypadków przeżywają stres średnio 2-3 razy w tygodniu. W porównaniu do średniej krajowej procent szeregowych pracowników odczuwających stres w pracy wynosi 37\% (http://weblog.infopraca.pl/2012/02/ktojest-najbardziej-zestresowany-kadra-managerska-sredniego-szczebla/, [dostęp: 20.04.2012]). Dodatkowo 20\% pytanych menedżerów skarży się na bezpośrednie skutki stresu objawiające się poprzez zaburzenia psychiczne i wegetatywne. Menedżerowie średniego szczebla w 44\% miewają trudności $\mathrm{z}$ radzeniem sobie ze stresem $(70 \%$ pracowników

* Katedra Edukacji Muzycznej, Wydział Kompozycji, Teorii Muzyki, Dyrygentury, Rytmiki i Edukacji Muzycznej, Akademia Muzyczna w Łodzi. 
szeregowych nie ma z tym trudności) (Ibidem). Są przeciążeni pracą i obowiązkami oraz mają zbyt mało czasu na odpoczynek i relaks. Nie udaje im się również godzenie pracy z życiem prywatnym. Dodatkowym źródłem stresu, dla tej grupy zawodowej, jest strach i lęk związany z możliwością utraty pracy. Niepewność (brak stabilności) zatrudnienia, zwłaszcza w czasach kryzysu, staje się główną troską dla wielu pracowników średniego i wyższego szczebla (Anam, 2011, http://www.firma.egospodarka.pl/article/articleprint/53587/-1/47, [dostęp: 20.04.2012]).

\section{Stres w pracy menedżera}

Na przewlekły stres i dystres ${ }^{1}$ narażeni są w szczególności menedżerowie oraz osoby zajmujące wysokie stanowiska w hierarchii firmy. Grupą największego ryzyka są osoby żyjące w niebezpiecznych warunkach, poddane ogromnej dyscyplinie pracy, lecz niepotrafiące odpowiednio wydatkować i zarządzać swoją własną energią życiową (por. Żółcińska, 2005). „Specyfiką stresu menedżerskiego jest nieustanne oscylowanie na granicy ryzyka, konieczność podejmowania trudnych decyzji, finansowa i moralna odpowiedzialność za innych" (Ibidem). Do tego dochodzi dodatkowy stres związany z częstym przemieszczaniem się, pracą od rana do nocy czy w każdy dzień tygodnia. Przemęczenie pracą zawodową (pośpiech, natłok codziennych obowiązków, ilość godzin spędzanych w pracy) jest jednym z podstawowych czynników generujących stres naszych czasów, zwłaszcza dla menedżerów.

Praca na stanowisku menedżera wiąże się z ogromną ilością obowiązków, a także z ich wysoką jakością (Pawełczyk, 2007). Najczęściej stres występuje u menedżera w momencie rozbieżności planów, niedopasowania wymagań do posiadanych umiejętności, presji i braku czasu, gonitwy terminów, spoczywającej na nim odpowiedzialności itd. (Ibidem). Całość tego procesu rzutuje w następnej kolejności na ogólne (zwłaszcza finansowe) wyniki przedsiębiorstwa, podejmowanie kolejnych przedsięwzięć i projektów, komunikację w firmie, motywowanie podwładnych i inne.

W klinikach zajmujących się schorzeniami psychosomatycznymi w Niemczech obserwowany jest znaczący wzrost pacjentów, którzy są menedżerami średniego i wyższego szczebla. Przed dziesięcioma, piętnastoma laty ta grupa zawodowa nie podejmowała się leczenia ze względu na dokuczliwy stres. Powody tego są zdaniem prof. Schedlowskiego następujące: „znaczne przeciążenie pracą (praca w złych warunkach) dla

1 Dystres to rodzaj nieprzyjemnego stresu związanego z lękiem, bólem i cierpieniem; por. H. Seyle (1977). 
większości menedżerów, ciągła dostępność przez telefon i w komunikacji on-line, podwójne obciążenie - pracą i rodziną, długotrwałe podróże, częste przebywanie w różnych strefach czasowych i klimatycznych oraz ich częsta zmiana"”.

Stres w pracy menedżera występuje bardzo często, co wynika z licznych czynników bezpośrednio powiązanych ze specyfiką sprawowania funkcji kierowniczych (Syper-Jędrzejak, 2014, s. 151). Do podstawowych stresorów oddziałujących na współczesnego menedżera zaliczyć można między innymi: dużą osobistą odpowiedzialność za podległy mu zespół pracowniczy i jego wyniki, presję czasu oraz mnogość obowiązków. Potwierdziły to badania N. Ogińskiej-Bulik (2006) prowadzone wśród grupy kilkudziesięciu polskich menedżerów, które wskazały, że menedżerowie najczęściej przywoływali nadmierną ilość pracy oraz presję czasu jako najsilniejszy stresor (cyt. za: Wróblewska, 2013, s. 313). Ponadto za znaczny stresor uważa się także podejmowanie kluczowych decyzji przy znacznym ograniczeniu dostępnych informacji (Wachowiak, 2002; Penc, 2001).

Mnogość i narzucona terminowość zadań do wykonania to typowe zjawisko dla współczesnego menedżera. Powoduje to, że menedżer jest w pracy niemal cały czas, także po powrocie do domu. Brak możliwości oderwania się od obowiązków i problemów zawodowych wywołuje różne stany napięcia emocjonalnego, które obciążają psychikę, zmniejszając sprawność działania, a także przyczyniają się do powstawania konfliktów w życiu rodzinnym i w relacjach towarzyskich (Pocztowski, 2007, s. 398). Badania dowodzą, że kolejnym (dodatkowym) źródłem stresu dla biznesmena i menedżera jest brak miłości i akceptacji, czyli wsparcia emocjonalno-socjalnego w najbliższym otoczeniu.

W dalszej kolejności menedżerowie wymieniali: wszelkiego rodzaju zmiany w organizacji pracy, przejście na nowe stanowisko - jako czynniki wymuszające wzmożoną aktywność i zaangażowanie oraz konieczność opanowania nowych umiejętności (Syper-Jędrzejak, op. cit., s. 155-156). Trzecią dużą kategorię przyczyn powstawania stresu u menedżerów stanowią sytuacje konfliktowe w pracy. „Czynnik ludzki”, czyli praca z osobami konfliktowymi, konieczność egzekwowania pewnych zachowań czy zadań od ludzi oraz zarządzanie nimi, również zostały ocenione jako czynniki stresogenne (Ibidem).

2 Oryginalne brzmienie: „massive Arbeiterdichtung für die meisten Führungskräfte, ständige Verfügbarkeit durch Handy und Online-Kommunikation, Doppelbelastung in Beruf und Familie, dauerndes Reisen, häufig über Zeit - und Klimazonen hinweg" (Kröher, 2005). 


\section{Cechy menedżera w korporacji międzynarodowej}

W ostatnich latach w Polsce stale rośnie liczba korporacji, a co za tym idzie, również zwiększa się liczba menedżerów w nich pracujących. Terminem menedżer określamy osobę zarządzającą przedsiębiorstwem lub jego częścią. Jego celem jest zarządzanie, czyli planowanie, koordynowanie, organizowanie, kontrolowanie oraz kierowanie działaniami firmy. W zależności od pozycji $\mathrm{w}$ organizacji wyróżniamy menedżerów liniowych (np. brygadziści w przedsiębiorstwie przemysłowym), średniego szczebla (np. kierownik działu przedsiębiorstwa) i najwyższego szczebla (prezes przedsiębiorstwa).

Na sukces menedżera pracującego w korporacjach międzynarodowych - oprócz jego kompetencji zawodowych - będą się składały takie cechy jak: wysokie umiejętności interpersonalne ( $w$ tym większa orientacja na ludzi, niż na zadania), zdolności lingwistyczne, motywacja do zamieszkania za granicą, ciekawość kulturowa oraz otwartość. Kolejnymi cechami dobrego pracownika wyższego szczebla w korporacji powinna być: elastyczność, cierpliwość, wyrażanie szacunku wobec innych, kulturowa empatia oraz poczucie humoru (Bieniek, Steinerowska, 2014, s. 39).

Jedną z najistotniejszych kompetencji menedżera międzykulturowego jest inteligencja emocjonalna, na którą składa się: samoświadomość, samoregulacja, motywacja, wysoko rozwinięta empatia i umiejętności społeczne oraz talent poruszania się w różnych kulturach (Sitko-Lutek, 2002). Dodatkowo oczekuje się od menedżera transkulturowego, aby posiadał wysoką autonomię osobistą oraz wysoki poziom tolerancji na niepewność. Kolejną pożądaną cechą współczesnego menedżera (przedsiębiorcy), pracującego poza granicami kraju, jest umiejętność zarządzania różnicami kulturowymi.

Profil menedżera międzykulturowego, oprócz podstawowych kompetencji z zakresu pełnionej roli i funkcji, musi dodatkowo uwzględniać komponenty związane ze specyfiką rynku międzynarodowego. Menedżera globalnego musi charakteryzować duża wrażliwość na potrzeby kulturowe, zdolność adaptacji i uczenia się od innych, duch przedsiębiorczości oraz komunikatywność w warunkach różnorodności kulturowej (Bieniek, Steinerowska, op. cit., s. 40).

Innym wyzwaniem, stojącym przed menedżerem globalnym, jest umiejętne radzenie sobie z tzw. szokiem kulturowym, często będącym zjawiskiem nieuniknionym. Termin ten dotyczy osób przebywających dłużej poza granicami swojego kraju (Sitko-Lutek, 2002, s. 92; zob. także: Sitko-Lutek, 2004). Menedżerowie pracujący w krajach odmien- 
nych kulturowo nierzadko przeżywają emocje, będące kontaminacją niepewności, dezorientacji i lęku, wynikającego z konieczności rozumienia zagranicznych konwenansów oraz tworzenia nowych relacji na poziomach zawodowym i społecznym (Bieniek, Steinerowska, op. cit., s. 41).

Aby zmniejszyć przeżywany szok kulturowy wskazane jest zastosowanie procesu adaptacji i akulturacji do nowych warunków. Akulturacja umożliwia przyswojenie kompetencji kulturowej, związanej m.in. z opanowaniem nowego języka, kreowaniem pożądanych zachowań społecznych czy budowaniem nowej tożsamości na podstawie istniejących wzorców kulturowych. Skuteczność procesu akulturacji zależna jest od osobistych predyspozycji osób przebywających w placówkach międzynarodowych (Szopski, 2005, s. 132).

\section{Stres a praca w warunkach międzykulturowych}

Praca w korporacji - zwłaszcza międzynarodowej - łączy się z realizowaniem ciekawych projektów, indywidualnych celów, rozwojem i samorealizacją, posługiwaniem się na co dzień językiem obcym, pracą z ciekawymi ludźmi i oczywiście odpowiednim wynagrodzeniem. Korporacja z jednej strony wiele oferuje (np. pakiety sportowe, dodatkowe ubezpieczenie medyczne, wyjazdy zagraniczne, imprezy integracyjne), ale z drugiej wiele żąda od swojego pracownika (poświęcenia, pracy po godzinach, pełnego zaangażowania).

Zarządzaniu zasobami ludzkimi w środowisku międzynarodowym towarzyszą zarówno problemy kulturowe, jak i personalne. Problemy te - zdaniem Cz. Zająca (2012, s. 71) - obejmują m.in.: trudności z asymilacją w nowym środowisku, szok kulturowy, „cynizm korporacyjny”, zjawisko wielowładztwa oraz stres menedżerów i pracowników wynikający także $\mathrm{z}$ wielokulturowego charakteru ich środowiska pracy.

Ważnym czynnikiem jest sytuacja ekonomiczno-polityczna danego kraju, jego położenie geograficzne (klimat, pogoda), zmiany czasowe, jet lag itp. Nie wspominając o samej podróży, czasie i trudzie przemieszczania się, poszukiwania odpowiedniego hotelu i wyżywienia, czy też konieczności dostosowania się do nowych warunków (nie tyko bytowych, ale także kulturowych). Coś, co na pierwszy rzut oka może nas fascynować (np. jedzenie, białe noce, monsuny, czy kultura danego kraju), w dłuższej perspektywie może stać się nowym czynnikiem stresogennym.

Kolejnym aspektem wpływającym na jakość pracy menedżera w środowisku międzynarodowym jest przepływ informacji, sposób komuni- 
kacji z partnerami zagranicznymi, czyli inna (obca) kultura organizacyjna. Sama umiejętność stworzenia odpowiednich relacji w stosunkach międzynarodowych, zarządzanie międzynarodowym zespołem ludzi, czy też sztuka prowadzenia negocjacji, z jednej strony są nowymi wymaganiami stawianymi przed osobą pracującą poza centralą kraju macierzystego firmy, a z drugiej czynnikami dodatkowo stwarzającymi napięcia w pracy. To samo dotyczy umiejętności rozwiazywania problemów oraz sposobów motywowania współpracowników.

Czynnikiem stresu mogą być również stosowane w danym kraju - a obce dla naszego menedżera - systemy norm i wartości, język, czy też dominująca religia (patrz: kraje arabskie). Styl i język komunikowania się oraz szeroko pojęta kultura organizacyjna firmy, z którą się współpracuje na arenie międzynarodowej, także będzie wyzwaniem. Ostatnim aspektem są uwarunkowania kulturowe, inne sposoby spędzania czasu wolnego i tradycje kulturowe danego kraju.

Współczesne przedsiębiorstwa działające na rynkach zagranicznych posiadają pracowników i kontrahentów z różnych krajów i kultur. Prezentują oni odmienne systemy wartości, normy zachowań i obyczajów. To wszystko powoduje, że ludzie (pracownicy, menedżerowie) inaczej postrzegają rzeczywistość, w inny sposób myślą, czują i działają, co trzeba mieć na uwadze wysyłając pracownika np. na dwuletni kontrakt do krajów azjatyckich.

\section{Skutki stresu pracy menedżera pracującego w środowisku międzynarodowym}

Praca menedżera - zwłaszcza w korporacjach międzynarodowych - może z dużym prawdopodobieństwem po kilku latach intensywnej pracy doprowadzić do wypalenia zawodowego. Problem ten dotyczy $70 \%$ firm (Wypaleni przez Mordor. Praca w korporacji doprowadziła mnie do skrajnego wyczerpania..., http://gospodarka.dziennik. pl/praca/artykuly/492192,praca-w-korporacji-wypaleni-przez-mordorrozmowa-z-katarzyna-skoczek.html, [dostęp: 20.09.2016]). Wydłużone godziny pracy, wyśrubowane wymagania, nadmiernie obciążenie obowiązkami, nieprzemyślane, nieracjonalne oczekiwania - to często norma w pracy korporacyjnej. Przeciążenie może być też efektem narastającej złożoności pracy. Pracownik nie ma czasu na odbudowę sił i odzyskanie równowagi, a także na satysfakcjonujące stosunki rodzinne, partnerskie oraz kontakty socjalne. Warto przy tym wskazać, że to zjawisko nie jest obecne jedynie w biznesie. Na wypalenie mocno 
narażeni są lekarze, pielęgniarki, psychologowie, pracownicy socjalni, pracownicy służb mundurowych, nauczyciele, dziennikarze czy programiści (Ibidem).

Koszty stresu, związane z pracą zawodową i jego konsekwencjami zdrowotnymi, wynoszą, według wyliczeń zawartych w EU Guidance of work-related stress, w krajach UE średnio ok. 20 mld rocznie (Anam, 2011, http://www.firma.egospodarka.pl/article/articleprint/53587/-1/47. [dostęp: 20.04.2012]). Według Komitetu ds. Zdrowia i Bezpieczeństwa koszty chorób związanych ze stresem jedynie w Wielkiej Brytanii wynoszą rocznie $6,5 \mathrm{mln}$ dni roboczych. $0,5 \mathrm{mln}$ osób w tym kraju z powodu stresu opuszcza pracę biorąc dni wolne, co powoduje koszty dla danej instytucji (Hartley, 2005, s. 12). „Choroby spowodowane stresem są najczęstszym powodem absencji w pracy, opuszczaniem dni roboczych, brania zwolnienia" (Ibidem, s. 17).

Długo utrzymujący się stres, na zbyt wysokim poziomie, może prowadzić w konsekwencji do pogorszenia się zdrowia fizycznego, a jego konsekwencją będą zmiany fizyczne, które uwidocznią się poprzez powstanie różnych dysfunkcji narządów wewnętrznych (np. zespół jelita wrażliwego, wrzody żołądka, zawał, bóle głowy, bóle kręgosłupa) (Kronenberger, 2006, s. 81). Najczęściej pojawiają się w takich przypadkach dolegliwości ze stronu układu oddechowego, krwionośnego, trawiennego lub kostno-stawowego.

Skutki stresu nie są tylko natury fizycznej, lecz także emocjonalnej i poznawczej. Występowanie stresu nie jest tylko związane z obniżeniem nastroju, samooceny, czy też dobrego samopoczucia. Intensywność jego występowania jest ściśle związana także ze spadkiem sprawności intelektualnej oraz zakłóceniem elastyczności myślenia (Zimbardo, 1999, s. 498). Reakcje stresowe w obszarze poznawczym obejmują również zakłócenia procesów oceny oraz rozwiązywania problemów, procesów pamięci, podejmowania decyzji czy też zwężenia zakresu uwagi (Ibidem). Pod wpływem sytuacji stresowych zaczynamy działać i myśleć w sposób schematyczny, stereotypowy, co automatycznie prowadzi do usztywnienia procesu myślenia oraz wyłączenia twórczych i kreatywnych kanałów działania.

Skutki stresu mogą objawiać się nie tylko poprzez dolegliwości natury fizycznej, emocjonalnej, ale też zdrowotnej. Najczęstszą reakcją na stres jest nadużywanie alkoholu, papierosów bądź innych używek (np. narkotyków, dopalaczy, leków, suplementów diety). Oprócz napojów wysokoprocentowych częstą reakcją na stres może być objadanie się, nadużywanie kawy czy napojów pobudzających. Życie w długotrwałym stresie może także prowadzić do zwiększonego ryzyka wypad- 
ków (np. podczas prowadzenia samochodu). Nadmiar wrażeń oraz wysoki poziom napięcia w ciągu dnia prowadzi w prostej linii do zaburzenia snu, problemów z zasypianiem, bądź przesypianiem całej nocy.

\section{Podsumowanie}

Do głównych czynników wywołujących stres u menedżerów pracujących $\mathrm{w}$ środowisku międzynarodowym należą m.in.: wysokie tempo pracy (pośpiech), emocjonalny ladunek pracy, nadmiar obowiązków, rutyna, niemożliwość wykorzystania własnych umiejętności, monotonne zadania, brak wsparcia u kolegów, brak autonomii w działaniu, brak udziału w podejmowaniu decyzji oraz konflikt ról (Anam, 2009, www.eGospodarka.pl, [dostęp: 20.04.2012]).

Pracując jako menedżer w środowisku międzynarodowym trzeba pamiętać, że jest to zawód obarczony zwiększonym ryzykiem powstawania stresu. Zalecana jest zatem równowaga typu work-life balance, dokładne obserwowanie sygnałów płynących z naszego ciała, satysfakcjonujące życie prywatne oraz uprawianie sportu i stosowanie diety. Odpowiednia ilość wypoczynku, relaksu i czasu wolnego, która będzie proporcjonalna do czasu pracy, jest najsilniejszym elementem walki z wystąpieniem symptomów stresu zawodowego.

Każdy musi znaleźć odpowiednie dla siebie sposoby odreagowania zarówno napięcia fizycznego, jak i psychicznego, które nam towarzyszy w pracy zawodowej. Menedżerowie są szczególnie narażeni na odczuwanie stresu związanego zwłaszcza z pracą $\mathrm{w}$ międzynarodowej korporacji i tym bardziej powinni być uwrażliwieni na jego symptomy. Posiadanie umiejętności walki ze stresem jest nowym wyzwaniem dla menedżerów.

Nowa gospodarka preferuje menedżerów odpornych na stres, czyli posiadających kompetencje miękkie (dotyczących przede wszystkim zarządzania własną osobą, własną motywacją oraz umiejętnościami interpersonalnymi np.: umiejętność rozwiązywania problemów) oraz znających techniki i strategie radzenia sobie ze stresem. Współczesny menedżer powinien bowiem posiadać nie tylko uniwersalne kompetencje (poznawcze, społeczne, osobiste, biznesowe, firmowe, menedżerskie) w zakresie pełnionych obowiązków zawodowych, lecz przede wszystkim kompetencje gwarantujące efektywne funkcjonowanie w środowisku wielokulturowym (por. Bieniek, Steinerowska, 2014). 


\section{BIBLIOGRAFIA}

Anam R. (2009), Stres w pracy coraz większy, www.eGospodarka.pl, [dostęp: 20.04.2012].

Anam R. (2011), Stres w pracy - jak go minimalizować?, http://www.firma.eGospodarka.pl/article/articleprint/53587/-1/47, [dostęp: 20.04.2012].

Bieniek I., Steinerowska S. (2014), Kompetencje międzykulturowe na mapie kompetencji zawodowych menedżera, ,Zeszyty Naukowe Politechniki Śląskiej. Organizacja i Zarządzanie", z. 71.

Hartley M. (2005), Stres w pracy, Wydawnictwo Jedność, Kielce.

Kronenberger M. (2006), Muzykoterapia. Podstawy teoretyczne do zastosowania muzykoterapii w profilaktyce stresu, Wydawnictwo Mediatour, Szczecin.

Kröher M.O.R. (2005), Wie Sie Druck abbauen, „Manager Magazin Online”, http://www.managermagazin.de/magazin/article/0,2828-,druck-3375.html, [dostęp: 20.04.2012].

Ogińska-Bulik N. (2006), Stres zawodowy w zawodach ustug społecznych: źródta, konsekwencje, zapobieganie, Difin, Warszawa.

Pawełczyk I. (2007), Stres w pracy menedżera, http://nf.pl/portalwieszjak.pl/praca/ 214286/Stres-w-pracy.html, [dostęp: 20.04.2012].

Penc J. (2001), Kreowanie zachowań w organizacji, Wydawnictwo Placet, Warszawa.

Polskie Towarzystwo Wspierania Przedsiębiorczości, Praca menadżera a stres $w$ pracy, http://www.wnp.pl/drukuj/17181_1.html, [dostęp: 12.05.2014].

Pocztowski A. (2007), Zarządzanie zasobami ludzkimi: strategie, procesy, metody, PWE, Warszawa.

Seyle H. (1977), Stres okiełznany, tł. T. Zalewski, Państwowy Instytut Wydawniczy, Warszawa.

Sitko-Lutek A. (2002), Organizacja przyszłości oparta o globalnych liderów i globalna kulturę, [w:] Grudzewski W., Hejduk I. (red.), Przedsiębiorstwo przyszłości-wizja strategiczna, Difin, Warszawa.

Sitko-Lutek A. (2004), Kulturowe uwarunkowania doskonalenia menedżerów, Wydawnictwo Uniwersytetu Marii Curie-Skłodowskiej, Lublin.

Smith M., Segal R. (2011), Stress Management. How to reduce, prevent, and cope with stress. Helpguide.org, http://www.helpquide.org-/mental/stress_-management_rel ief_coping.-html, [dostęp: 12.09.2014].

Syper-Jędrzejak M. (2014), Strategie radzenia sobie ze stresem w pracy menadżera, „Humanizacja pracy", $\mathrm{nr} 4$.

Szopski M. (2005), Komunikowanie międzykulturowe, WSiP, Warszawa.

Wachowiak P. (2002), Profesjonalny menedzer, Difin, Warszawa.

Wróblewska V. (2013), Źródła stresu w pracy zawodowej menedżerów, „Zeszyty Naukowe Uniwersytetu Przyrodniczo-Humanistycznego w Siedlcach", nr 98.

Wypaleni przez Mordor. Praca w korporacji doprowadzita mnie do skrajnego wyczerpania..., http://gospodarka.dziennik.-pl/praca/artykuly/492192,praca-w-korporacji-wy paleni-przez-mordor-rozmowa-z-katarzyna-skoczek.html, [dostęp: 20.09.2016].

Zając Cz. (2012), Kulturowe i personalne problemy zarządzania zasobami ludzkimi $w$ międzynarodowych grupach kapitałowych $w$ świetle badań empirycznych, ,Zarządzanie Zasobami Ludzkimi”, nr 6 (89).

Zimbardo P.G. (1999), Psychologia i życie, Wydawnictwo Naukowe PWN, Warszawa. 
Żółcińska W., Stres menadżera, http;//ceo.cxo.pl/artykuly-/druk/46054/-Stres.mene dzera.html, [dostęp: 12.09.2014].

http://weblog.infopraca.pl/2012/02/kto-jest-najbardziej-zestresowany-kadra-managerskasredniego-szczebla/, [dostęp: 20.04.2012].

\title{
STRESS OF MANAGERS WORKING IN THE INTERCULTURAL AND INTERNATIONAL ENVIRONMENT
}

\begin{abstract}
This text will presenting the problems of the modern manager working in international corporations and conditions. It is this group of employees of the company is exposed to a large dose of stress related to working conditions, pressure of time and the number of terms/projects. You can even say that a new skill - valued in the modern manager - is a high resistance to stress and work-life balance.
\end{abstract}

Keywords: manager, stress, multinational corporation, intercultural conditions. 